\title{
The Occurrence of Multiple Sclerosis in the Hutterites of North America
}

\author{
Walter J. Hader, T. Peter Seland, Mary B. Hader, Colleen J. Harris \\ and Dennis W. Dietrich
}

\begin{abstract}
Objective: To report the occurrence, clinical characteristics and genealogical analysis of multiple sclerosis in the Hutterites of North-Western United States and Western Canada. Background: The incidence of multiple sclerosis is reported to be lower or rare in certain ethnic groups and genetic isolates and was previously observed to be absent in the Hutterite population. Methods: After longterm surveillance, six patients were identified and clinical examinations and laboratory investigations including VER and MRI were completed. Results: The six cases included two brothers, two first cousins, male and female, another male and female, all representing two of the three endogamous groups of Hutterites, are linked to two common ancestors through lines of descent dating to 1723. The individual pedigrees were analyzed from extensive genealogical records covering eight generations. Conclusion: The incidence of multiple sclerosis in Hutterites is low in a high risk area of North America. A specific mode of inheritance pattern has not been established and a common founder effect may play a role in the development of multiple sclerosis. The genetic contribution of the Hutterites seems greater than previously recognized.
\end{abstract}

RÉSUMÉ: La sclérose en plaques chez les Hutterites d'Amérique du Nord. Objectif: De rapporter la fréquence, les caractéristiques cliniques et l'analyse généalogique des cas de sclérose en plaques chez les Hutterites du nord-ouest des États-Unis et de l'ouest du Canada. Introduction: L'incidence de la sclérose en plaques est rapportée comme étant plus basse ou rare dans certains groupes ethniques et isolats génétiques et on a observé antérieurement que cette maladie était absente chez les Hutterites. Méthodes: Après une surveillance prolongée, six patients ont été identifiés et nous avons procédé chez eux à des examens cliniques et à une investigation qui incluait les potentiels évoqués visuels et la résonance magnétique nucléaire. Résultats: Les six cas incluaient deux frères, deux cousins germains, soit un homme et une femme, ainsi qu'un autre homme et une autre femme, tous membres de deux des trois groupes endogames de Hutterites. Ces cas remontent à deux ancêtres communs en 1723. Les arbres généalogiques individuels ont été tirés de fichiers généalogiques considérables couvrant huit générations. Conclusions: L'incidence de la sclérose en plaques chez les Hutterites est faible dans les régions a haut risque de l'Amérique du Nord. Un mode d'hérédité spécifique n'a pas été établi et un effet fondateur pourrait jouer un rôle dans le développement de la sclérose en plaques. La contribution génétique des Hutterites semble plus grande qu'on ne le croyait antérieurement.

Can. J. Neurol. Sci. 1996; 23: 291-295

The incidence of multiple sclerosis (MS) is reported to be lower or rarer in certain ethnic groups residing in high risk areas, including the Orientals, Blacks, Hungarian Gypsies, North American Indians, Lapps and Arabs, than in Caucasoids. ${ }^{1}$ Racial variations, ${ }^{2}$ higher familial incidence for MS than in the general population, ${ }^{3}$ and the higher concordance in monozygotic twins than in dizygotic twins ${ }^{4}$ provide evidence for a genetic contribution to the cause of the disease. Associations have been reported between MS and certain histocompatibility antigens (HLA) on chromosome $6 .^{5}$ The influence of T-cell receptor genes at other loci, which regulate the immune response contributing to the pathogenesis remains unproven. ${ }^{6}$ Geographic and racial differences, studies in migration and clustering, can be interpreted to support roles for genetics and/or environment in the etiology of MS.
The Western Canadian provinces and the North-Western United States comprise an area of high incidence and prevalence for MS. ${ }^{7-11}$ MS was observed to be rare or absent in the Hutterite population. ${ }^{12.13}$ After long-term surveillance, we report six cases in the Hutterite population. The family data are believed to support the hypothesis of a genetic factor in the etiology of MS.

From the Department of Rehabilitation Medicine, College of Medicine, University of Saskatchewan, Saskatoon, (W.J.H., M.B.H.); Calgary General Hospital, Department of Clinical Neurosciences, Calgary, (P.T.S., C.J.H.); and Columbus Professional Building. Adult and Child Neurology, Great Falls. Montana. (D.W.D.)

RECEIVED JANUARY 26, 1996. ACCEPTED IN FINAL FORM MAY 29, 1996

Reprint requests to: Dr. W.J. Hader, Department of Rehabilitation Medicine, Saskatoon City Hospital, Saskatoon, Saskatchewan, Canada S7K 0M7 


\section{The Population}

The Hutterite Brethren constitute a religious and genetic isolate residing on highly mechanized communal farms (colonies) in the four Western Canadian provinces and in the states of North Dakota, South Dakota, Washington, Montana and Minnesota.

The Hutterites, a Swiss Anabaptist movement, originated in the Tyrol region of Austria around $1525 . .^{14}$ Following numerous migrations an original group of 1,265 Hutterites emigrated to the Dakota territories in the USA from the Ukraine in Russia between 1874-1879. A population of 443 settlers formed three original colonies in South Dakota and the establishment of these colonies formally initiated three endogamous subdivisions, the Dariusleut, Lehrerleut and Schmiedeleut and have maintained their separate identities and endogamous marriage patterns. The remaining two-thirds, the Prairieleut settled on individual homesteads in the same region.

The individual leuts expanded and subdivided into further colonies and eventually moved to the Canadian prairie provinces of Manitoba and Alberta in 1918 and to Saskatchewan in 1952. The Hutterite population is closed to immigration and there has been very little intermarriage between the groups since 1918 . The three leuts form the legal entity of the Hutterian Brethren Church. ${ }^{14}$

There are 362 colonies in the three Canadian prairie provinces and the North-Western United States with an average of 80 persons per colony and a range of $60-120$. The population of Hutterites in Western Canada is 21,495 (Canada census 1991) and 9,848 (estimated 1990) in the North-Western States. There are 17 traditional family names among the colonies.

A base population of 92 people is believed to have given rise to the current population. ${ }^{15}$ Because of the small number of immigrant ancestries, it has been estimated that the average relationship among the Hutterites is closer than second-cousins. ${ }^{16}$ The Schmiedeleut of South Dakota and Manitoba trace their ancestry to 53 founders, ${ }^{17}$ the Dariusleut to 74 founders and the Lehrerleut to 69 founders. ${ }^{18}$ Each colony has a council with a head Minister and a secretary (or "BOSS") who manages the economic affairs.

\section{METHODS}

We investigated six cases of MS in the Hutterite population of Saskatchewan and Alberta, Canada, and Montana, United States of America who were ascertained over a five year period. The study was initiated by contacting the neurologists and Neuromuscular Clinics listed in the American Academy of Neurology registry. Contacts were also made with the MS clinics in Western Canada. Information of potential cases was first provided by a colony Minister and on follow-up visits to the colonies, these persons had a form of limb-girdle dystrophy that has been previously described in the Dariusleut and Schmiedeleut ${ }^{26}$ but not in the Lehrerleut population. Similar cases were observed in Alberta. The people were unfamiliar with the distinction between MS and MD and some cases of MS could have been missed. There is close communication between the colonies through the Minister's council.

The population is very health conscious and open to research in the communities. The utilization rate of medical services is high and they are quite open to receiving medical information and care, including some forms of alternative therapies.

The first or index female case was identified by a Hutterite member in Saskatchewan who led to a second person, a male first cousin. Both were visited on two separate Lehrerleut colonies in Montana. A third person identified by the male cousin but unknown to the first case, was living in southwestern Alberta, and provided the history of an affected brother living in southeastern Saskatchewan. A fifth case listed on the Saskatchewan clinic registry was now confirmed and the sixth person was identified by a case informant upon a follow-up by telephone. The colonies to which the six cases belonged were in Saskatchewan and Montana, approximately 400 miles apart.

Visits were also made to South Dakota and to the first Schmiedeleut colony established in 1874 near Yankton, South Dakota. The local records keeper/historian recalled no cases of MS in this leut.

The medical records for the index and the five other cases were obtained through family physicians and neurologists. The results of previous laboratory investigations and spinal fluid examinations were accepted if available. Five of the six patients had been seen by at least two neurologists and arrangements were made for review of the first four cases at the Calgary MS Clinic by the study neurologist who confirmed the diagnosis based on standard diagnostic criteria. ${ }^{19}$ The visual evoked responses (VER) and MRI scanning were done on all six individuals. Urine homocystine and methylmalonic acid, and plasma methionine levels were determined on the first four cases.

\section{Case Histories}

\section{Patient 1}

The index case is a 47-year-old female who at age 28 complained of left-sided weakness, incoordination and diplopia which resolved with minimum residual. The incoordination of the left leg and tingling of the left hand recurred in 1984 and persisted 18 months. There was a complete loss of vision in the left eye, with subsequent recovery of light perception at this time. Six months later weakness and ataxia occurred in both legs and recovery was incomplete. Five years later, in 1991, the gait remained mildly impaired with mild left hemiparesis. Vibration was impaired in the left foot. Left optic disc pallor and pupillary afferent defect were present. The course has been relatively quiescent since 1986.

\section{Patient 2}

This 56-year-old male, a first cousin of the index case, developed right optic neuritis in 1967 at age 28 with full recovery. Fourteen years later he developed moderately severe quadraparesis with bowel and bladder retention and a sensory level to the shoulders. He was unable to feed himself and had severe difficulty with walking. After six weeks he had slight impairment of tandem gait and was fully recovered in 3 to 4 months.

He experienced similar severe attacks each of the next four years, characterized by diplopia and incoordination of the legs lasting about 4 weeks. In 1990 he developed some stiffness of the right leg with limp, dysarthria and fatigue. Approximately a year later he developed some dragging and stiffness of the left leg which recovered. There has been no recurrence since.

\section{Patient 3}

This 37-year-old left handed male, had developed coldness of the left leg and arm with gradual weakness in 1984 at age 26 . He also had fatigue and aching and numbness in the fingers of the right hand. All of these symptoms resolved. Two months later he developed bilateral blurred vision with inability to read followed by recovery in one month. Four years later he developed acute weakness, loss of balance and incoordination, intermittent diplopia and intermittent urgency and frequency of micturation. Three years later the visual acuity in the left eye was $20 / 60$, mild left-sided ataxia was present with impaired vibration and a gait difficulty. This course has been slowly progressive and the patient remains ambulatory without aides. 


\section{Patient 4}

This 46-year-old male, a brother of patient 3, experienced "difficulty with legs" and pain and burning sensation of the feet at age 36 , followed by improvement over the next year. In 1986 he developed unsteady gait, the right leg affected more than the left. Examination revealed visual acuity of 20/200 on the left and 20/100 on the right. The patient had rotatory nystagmus, increased tone and brisk reflexes in the legs and extensor plantar response on the left. The numbness and stiffness of the legs have slowly progressed and he now requires a wheelchair for longdistance mobility.

\section{Patient 5}

This 60-year-old male first complained of increasing weakness on the left side, with nocturnal spasms in the legs in 1983 at age 48 and left pyramidal signs were recorded. The course was very slowly progressive with appearance of bilateral signs in 1986 when an ankle brace was required. He developed paresthesia in the fingers two years later. In 1993 he was ambulatory with a brace. There was moderate weakness on the left side and laboratory investigations confirmed the diagnosis.

\section{Patient 6}

This 39-year-old female noticed numbness and tingling of the left little finger in 1990 at age 36 . These symptoms spread to involve the whole left arm and the right hand over several months. In 1993 she developed numbness of the chest and vaginal area followed by improvement. She experienced Lhermitte's phenomenon with tingling down the left arm, back and abdomen, that was still present two years later. Examination showed mild left arm weakness and diffuse decrease to light touch and pain, possibly related to a wringer washing machine accident as a child. These findings were similar two years later and the dysesthesia of the left arm had improved.

\section{ResUlts}

Six clinical cases of definite multiple sclerosis are reported, with the diagnosis supported by neurological examination and laboratory evidence in each case. Three cases are in the Lehrerleut and three in the Dariusleut subdivisions in this large Hutterite kinship. The female index case and her male first cousin, and a third female live on separate Lehrerleut colonies in Montana. The two brothers on Dariusleut colonies, one in Saskatchewan and one in Alberta, prior to this investigation had no previous contact with the three relatives in Montana. The two brothers had lived together 17 years. Each of the six live and had the onset of the disease in separate rural colonies. The six cases, representing 3 family names, all trace back to two common founders (Figure).

There are a total of 49 siblings in the 5 family branches of the patients. Two brothers have four children each, under age 20. The index case has one child age 20 and the male first cousin has no children. The remaining male has four children, ages 32-39.

The clinical course has been remitting and exacerbating in three cases, primary progressive in one and secondary progressive in two cases (Table). All remain independent in their life skills and ambulatory with very mild to moderate disability. Five cases had abnormal prolonged visual evoked responses and only three had a history of optic neuritis. The MRI reports of white matter abnormalities were consistent with MS in all six patients. Testing for urinary and plasma organic amino acids and serum methionine levels were all within normal limits. ${ }^{20,21}$

\section{Discussion}

The six cases of MS occur in two of the three endogamous groups, the Dariusleut and Lehrerleut, representing approximately

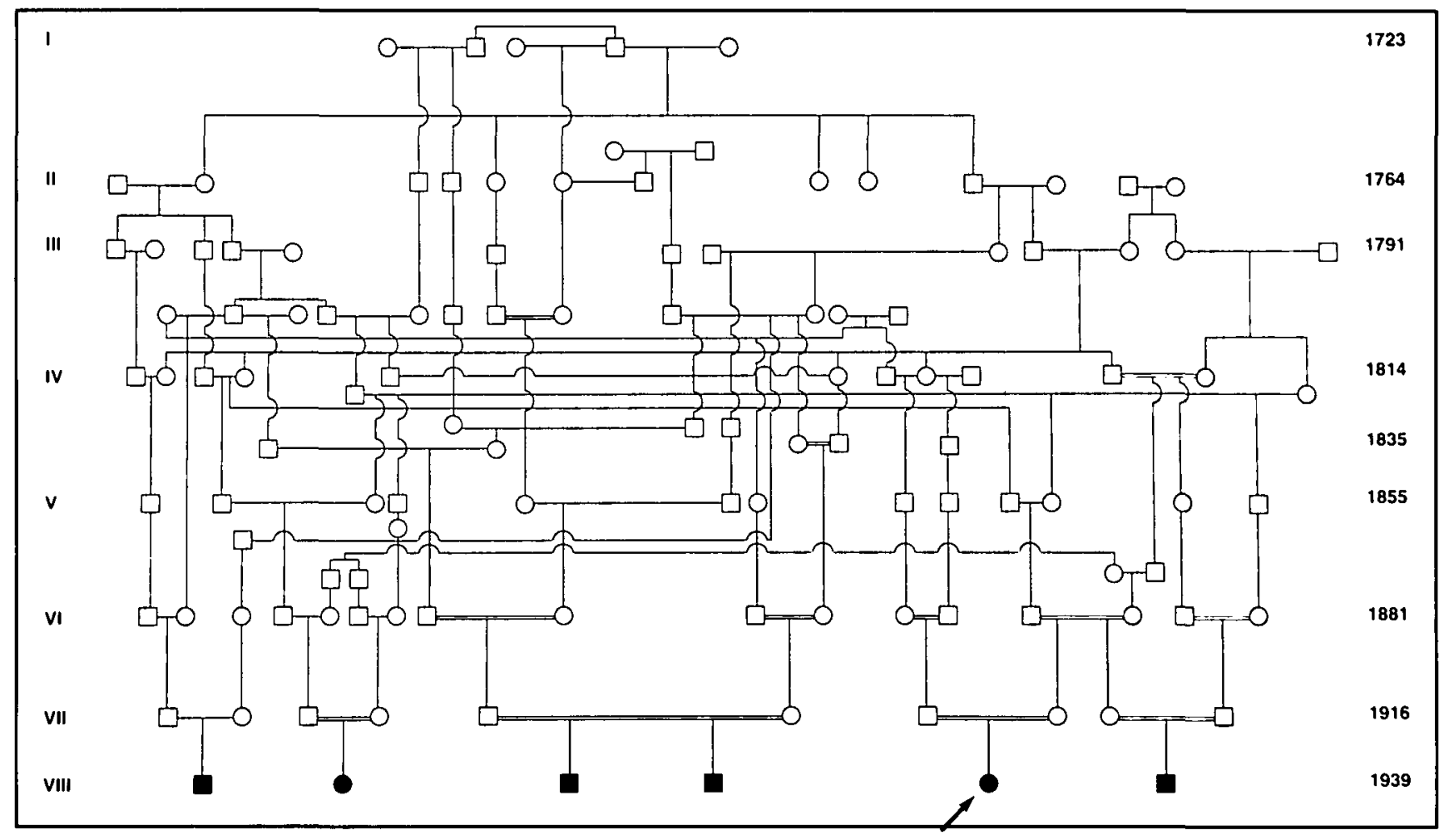

Figure: PEDIGREE OF MULTIPLE SCLEROSIS CASES IN HUTTERITES. The condensed pedigrees show affected members of sibships (dark sylmbols, female $(0)$ and male $(\square)$. The arrow indicates the index case. The double lines indicate consanguineous matings. The Roman numerals indicate the generations, and the right hand column the years of birth of successive generations. 
Table: Clinical Characteristics of Multiple Sclerosis in Hutterites.

\begin{tabular}{|c|c|c|c|c|c|c|c|}
\hline Patient & Date of Birth & Place \& Year of Onset & Age at Onset & Clinical $^{2}$ Course & KEDSS $^{1}$ & $\begin{array}{c}\text { Visual Evoked } \\
\text { Response (MSEC) }\end{array}$ & MRI \\
\hline 1. Female & 1948 & $\begin{array}{c}\text { Montana } \\
1976\end{array}$ & 28 & RR & 4.5 & $\begin{array}{l}\text { R-129 } \\
\text { L-NIL }\end{array}$ & + \\
\hline 2. Male & 1939 & $\begin{array}{c}\text { Montana } \\
1967\end{array}$ & 28 & RR & 1.5 & $\begin{array}{l}\text { R-144 } \\
\text { L-121 }\end{array}$ & + \\
\hline 4. Male & 1949 & $\begin{array}{c}\text { Saskatchewan } \\
1985\end{array}$ & 36 & SP & 6.5 & $\begin{array}{l}\text { R-108 } \\
\text { L-178 }\end{array}$ & + \\
\hline 5. Male & 1935 & $\begin{array}{c}\text { Saskatchewan } \\
1983\end{array}$ & 48 & PP & 6.0 & $\begin{array}{l}\text { R- } 107 \\
\text { L-107 }\end{array}$ & + \\
\hline
\end{tabular}

IKEDSS - Kurtzke Expanded Disability Status Scale

${ }^{2}$ Clinical Course - RR - Relapsing and Remitting

- PP - Primary Progressive

- SP - Secondary Progressive

21,495 individuals. These religious, genetic isolates live in highrisk areas where the prevalence is reported to be between 100 $220 / 100,000 .^{7-11}$ The estimated prevalence rate in these two groups is low at $28 / 100,000$. The expected number of cases was $21-46$.

The genealogy records made it possible to trace the ancestry of the parents of the six cases back to a single couple (Figure). The average relationship of spouses is closer than second cousins. Consanguinity increases the likelihood of homozygous expression of a recessive gene in a population. ${ }^{22}$ MS was not reported to be present in the previous or succeeding generations of each of the cases. The small number of cases in this study may reflect the age of the population in which it is estimated that $40 \%$ are under the age of 20 years, ${ }^{27}$ and have not reached the average age of onset of 33 years in the Hutterites. Numerous occurrences of rare recessive disorders are found in related Hutterite sibships. ${ }^{23-26}$

In the Old Order Amish, another genetic isolate, two cases of MS are reported with no immediate genealogical connection between the two families affected. ${ }^{28}$ Three cases of MS are reported in the old colony (Chortitza) Mennonites and multifactorial causation has been proposed. ${ }^{29}$

An autosomal recessive mode of inheritance with reduced penetrance, first proposed in twin studies, ${ }^{30}$ may be operative in this large isolate of inbreed families in the form of a single mutant gene. The founder effect may play an important role in the etiology. ${ }^{31}$ In the general population, however, family studies data excludes simple Mendelian inheritance and the data are best interpreted as support for susceptibility being polygenic. ${ }^{32.33}$

Evidence from studies in the outbred Canadian population ${ }^{34}$ strongly support the view that MS is a complex trait in which the genetic component comprises the effects of several loci.
These findings in the Hutterites suggest that one or more loci may be recessive.

The occurrence of MS in a genetic isolate as restricted as the Hutterites may help to solve the vexing problem of getting from linkage to locus in this complex trait. When linkages are found the presence of linkage disequilibrium in affected individuals may help in defining the susceptibility loci.

There is ongoing surveillance of the Hutterite population for further cases to provide resources for genetic analysis. This genetic isolate offers potential for the study of genetic epidemiology and molecular biology of multiple sclerosis.

\section{ACKNOWLEDGEMENTS}

We are indebted to the patients and their families for their assistance and cooperation, to Rev. J. Kleinsasser, Dr. Robert Griebel and Dr. Barry Boardman who provided the first links to the proband; to Dr. Marcus Johnson, Great Falls, Montana; Dr. John Noseworthy, Mayo Clinic, Rochester, Minnesota; Dr. Jim Hook and Dr. Ramsey Suidan, Medicine Hat, Alberta; Dr. C.T. Hing, Calgary; Dr. Carla Wallace (MRI) and Dr. Mary Ann Lee, Foothills Hospital, Calgary; Dr. Ken Koob, Sioux Falls, South Dakota, Dr. D.J. MacFadyen, Dr. J.R. Donat, University of Saskatchewan and MS Clinics Western Canada for clinical information; to Dr. Robin Casey and Wayne Hunter, Metabolic Disease Unit, University of Saskatchewan; the Medical Librarians, University Hospital, Saskatoon City Hospital, St. Paul's Hospital; Cheryl Salt, MS Clinic Coordinator and Bev Atkinson for data entry, Saskatoon City Hospital, Saskatoon, and Rita Casciano, University Hospital, London, Ontario for manuscript typing. We are grateful to Dr. G. Ebers, London, Ontario and Dr. D. Sadovnick, Vancouver, British Columbia for reviewing the manuscript.

Study supported by MS Society of Canada (Saskatchewan Division), and Birch Hills MS Group, Birch Hills, Saskatchewan. 


\section{REFERENCES}

1. Kurtzke JF. Epidemiologic contributions to multiple sclerosis: an overview. Neurology (NY) 1980; 30: 61-79.

2. Ebers GC, Bulman D. The geography of multiple sclerosis reflects genetic susceptibility. Neurology 1986; 36: (Suppl.) 108.

3. Compston A. Genetic factors in the aetiology of multiple sclerosis. In: McAlpines' Multiple Sclerosis. Matthew WB, ed. Churchill Livingstone, 1991: 301-319.

4. Ebers GC, Bulman D, Sadovnick AD, et al. A population based study of multiple sclerosis in twins. N Engl J Med 1988; 315: 1638-1642.

5. McDonald WI, Batchelor JR, Francis DA. The immunogenetics of multiple sclerosis. Trends Neurosci 1984; 7: 369-371.

6. Lynch GS, Rose JW, Petajan JH, Leppert M. Discordance of the Tcell receptor alpha-chain gene in familial multiple sclerosis. Neurology 1992; 42: 839-844.

7. Wynn DR, Rodriguez M, O'Fallon M, Kurland LT. A reappraisal of the epidemiology of multiple sclerosis in Olmstead County, Minnesota. Neurology 1990; 40: 780-786.

8. Hader WJ. Prevalence of multiple sclerosis in Saskatoon. Can Med J 1982; 127: 295-297.

9. Siedler HD, Nicoll W, Kurland LT. The prevalence and incidence of multiple sclerosis in Missoula County, Montana. Journal Lancet 1958; 78: 358-360.

10. Svenson L, Woodhead S, Platt GH. Regional variations in the prevalence rates of multiple sclerosis in the province of Alberta, Canada. Neuroepidemiology 1994; 13: 8-13.

11. Warren SA, Warren KG. Prevalence of multiple sclerosis in Barrhead County, Alberta. Canada. Can J Neurol Sci 1992; 19: $72-75$.

12. Lowry RB, Morgan K, Holmes TM, Gilroy SW. Congenital anomalies in the Hutterite Population: a preliminary survey and hypothesis. Am J Med Gen 1985; 22: 545-552.

13. McFarlin DE, Lachmann PJ. Hopeful genes and immunology. Nature 1989; 341: 693-694.

14. Hostetler JA. The Hutterite Society. Baltimore and London. The John Hopkins University Press, 1974.

15. Steinberg AG, Bleibtreu HK, Kurchynski TW, Martin AO, Kurchynski EM. In: Genetic studies on an inbred human isolate. Proceedings of the Third International Congress of Human Genetics. James F Crow, ed. 1967: 267-289.

16. Hostetler JA. History and relevance of the Hutterite population for genetic studies. Am J Med Gen 1985; 22: 453-462.

17. Martin AO. The founder effect in a human isolate. Am J Phys Anthrop 1970; 32: 351-368.

18. Fowlow B, Holmes MT, Morgan K, Snyder FF. Screening for methylmalonic aciduria in Alberta. A voluntary program with particular significance for the Hutterite Brethern. Am J Med Gen 1985; 22 : 513-519.
19. Poser CM, Paty DW, Scheinberg L, et al. New diagnostic criteria for multiple sclerosis: guidelines for research protocols. Ann Neurol 1983; 13: 222-231.

20. Carmel R, Watkins D, Goodman SI, Rosenblatt DS. Hereditary defect of cobalamin metabolism (cblG mutation) presenting as a neurologic disorder in adulthood. $\mathrm{N}$ Engl J Med 1988; 318 : 1738-1741.

21. Shevell MI, Carson W, Gavsie A, et al. Protein-bound homocysteine levels in familial multiple sclerosis. Clin Invest Med 1991; 14: 528.

22. McKusick VA. Selected aspects of the population genetics of recessive diseases. In: Medical Genetic Studies of the Amish. Baltimore: The John Hopkins University Press, 1978: 515-519.

23. Schurig V, Orman VA, Bowen P. Nonprogressive cerebellar disorder with mental retardation and autosomal recessive inheritance in Hutterites. Am J Med Gen 1981; 9: 43-53.

24. Pallister PD, Opitz JM. Brief clinical report: disequilibrium syndrome in Montana Hutterites. Am J Med Gen 1985; 22: 567-569.

25. Fujiwara TM, Morgan K, Schwartz RH, et al. Genealogical analysis of cystic fibrosis families and chromosome 7q RFLP haplotypes in the Hutterite Brethern. Am J Hum Genet 1989; 44: 327-337.

26. Shokeir MH, Rozdilsky B. Muscular dystrophy in Saskatchewan Hutterites. Am J Med Genet 1985; 22: 487-493.

27. Boldt ED. The recent development of a unique population: the Hutterites of North America. Prairie Forum 1983; 8: 235-241.

28. Cross HE, McKusick VA. A survey of neurological disorders in a genetic isolate. Neurology 1967; 17: 743-751.

29. Jaworski MA, Serverini A, Mansour G, et al. Genetic conditions among Canadian Mennonites: evidence for a founder effect among the old colony (Chortiza) Mennonites. Clin Invest Med 1989; 12: 127-141.

30. MacKay RP, Myrianthopoulos NC. Multiple sclerosis in twins and their relatives. Final Report. Arch Neurol 1966; 15: 449-462.

31. Nora JJ, Fraser FC. Genetic basis of heredity. In: Medical Genetics: Principles and Practice. Lea and Febiger Philadelphia, London, 1989: 73-94.

32. Sadovnick AD, Compston A. Epidemiology and genetics of multiple sclerosis. Current Opinion. Neurol Neurosurg 1992; 5: 175181.

33. Pratt RT, Compston ND, McAlpine D. The familial incidence of multiple sclerosis and its significance. Brain 1952; 74: 191232.

34. Sadovnick AD, Ebers GC. Genetics of multiple sclerosis. In: Antel JP, ed. Neurologic Clinics. Philadelphia: W.B. Saunders Co. 1995; 13: 99-117. 